\title{
O processo de construção da relação enunciador/enunciatário nas canções de Chico Buarque: Trocando em Miúdos ${ }^{1}$
}

\author{
On the Construction Process of the Utterer/ \\ Addressee Relation in Chico Buarque's \\ Songs: Trocando em Miúdos
}

Martha Lourenço Vieira*

Universidade Vale do Rio Doce - UNINCOR

RESUMO: O objetivo do artigo é analisar, à luz da teoria de Benveniste, algumas estratégias discursivas de construção das instâncias enunciativas presentes nas composições de Chico Buarque e os efeitos de sentido por elas produzidos. Inicialmente, são apresentados os princípios básicos do quadro teórico de referência, evidenciando como tais estratégias são utilizadas na construção da relação enunciador/enunciatário, em algumas das composiçôes deste autor. Em seguida, tomando como objeto de análise a canção Trocando em Miúdos, são analisados os modos de integração e articulação de tais estratégias, no processo enunciativo, com o intuito de demonstrar que a relação enunciador/enunciatário constitui-se como um fator essencial no processo de construção da autoria e da noção de sujeito.

PALAVRAS-CHAVE: enunciação; instância enunciativa; sujeito; autoria.

ABSTRACT: The objective of this article is to analyze, in light of Benveniste's theory, some discursive strategies of the construction of enunciative instances that are present in Chico Buarque's compositions, and the effect of the meaning produced by them. Initially, the basic principles of the theoretical scene of reference are presented, making evident how the strategies are used in the construction of the enunciator/enunciatee relation in some of the compositions of the author. Furthermore, based on the song "Trocando em miúdos" - the object of analysis - the mode of integration and articulation of the strategies are analyzed in the enunciative process, with the intention of demonstrating that the enunciator/enunciatee relation constitutes an essential factor in the process of construction of authorship and of the notion of subject.

KEYWORDS: articulation; enunciative instance; subject; authorship.

\footnotetext{
* criatura40@gmail.com

${ }^{1}$ Este texto é parte integrante da tese de doutorado: Opapel da composição da cena enunciativa no processo de aquisição do texto escrito, defendida em 2004, na Faculdade de Educação da Universidade de São Paulo/USP, sob a orientação da Profa. Dra. Maria Thereza Fraga Rocco.
} 


\section{Introdução}

Neste artigo explicitaremos e analisaremos, à luz da teoria de Benveniste, algumas estratégias discursivas de construção das instâncias enunciativas presentes nas composições ${ }^{2}$ de Chico Buarque e os efeitos de sentido por elas produzidos.

Primeiramente, apresentaremos os princípios e pressupostos básicos do quadro teórico tomado como referência, evidenciando, a título de exemplificação, como são utilizadas tais estratégias na construção da relação enunciador/ enunciatário, em algumas das composiçôes deste autor.

Em seguida, explicitaremos e analisaremos, de forma processual, como se integram e se articulam, no processo enunciativo, as estratégias evidenciadas e exemplificadas no primeiro momento, tomando como objeto de análise a canção Trocando em Miúdos.

Finalmente, com base na análise realizada nos momentos anteriores, buscaremos demonstrar que a relação enunciador/enunciatário constitui-se como um fator essencial no processo de construção da autoria e da noção de sujeito.

\section{O aparelho formal da enunciação e a noção de instância enunciativa}

Segundo Benveniste:

[t]odas as línguas têm em comum certas categorias de expressão que parecem corresponder a um modelo constante. (...) mas suas funções não aparecem claramente senão quando se as estuda no exercício da linguagem e na produção do discurso (1989, p. 68).

É nessa perspetiva que o autor apresenta um modelo explicativo do funcionamento da linguagem: o Aparelho Formal da Enunciação.

Nesse modelo, Benveniste considera que as condições de emprego das formas não são idênticas às condições de emprego da língua e propõe uma análise da língua no seu uso. Nesse sentido, Benveniste apresenta a enunciação como a possibilidade de se colocar a língua em funcionamento, num processo em que o locutor, no exercício da linguagem, na produção do discurso, atualiza o aparelho formal da enunciação, instanciando sua posição de locutor e, concomitantemente, instituindo o outro diante de si como seu alocutário.

${ }^{2}$ Ao longo do texto, também utilizaremos expressōes sinônimas como: canção, letra, texto, discurso, quando nos referirmos aos textos das músicas de Chico Buarque. 
Assim, podemos representar o modelo de enunciação de Benveniste na figura de um triângulo (NASCIMENTO, 2000), em que a relação en unciador(E)/ enunciatário $(\mathrm{Ea})$ se instaura, no tempo(T) e no espaço(L) do discurso, construindo a referência $(R)$.

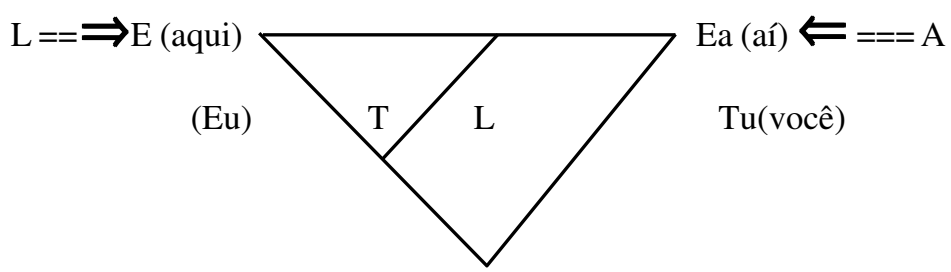

R (lá)Referencia Textual

\section{GRÁFICO 1}

Essa representação, em triângulo, visualiza bem todos os fatores constituintes do Aparelho Formal da Enunciação: um locutor(L), que se institui como enunciador (E) na e pela atividade linguística; um alocutário (A), co-instituído na e pela atividade linguística como enunciatário (Ea); uma referência $(\mathrm{R})$ que se constitui da necessidade do locutor e do alocutário falarem sobre um determinado assunto, ou seja, de co-referirem no e pelo discurso, criando e articulando outras entidades linguísticas para a especificação e/ou modalização de outras categorias envolvidas no processamento de textos (tempo, lugar, modalidade, etc.).

O aparelho formal da enunciação, representado através desse triângulo, é a condição básica para a produção do discurso oral ou escrito. Sempre que falamos ou escrevemos nos constituímos como enunciador de um discurso, colocando-nos, em nossa individualidade, enquanto $e u$ (E) por oposição a tu (Ea) e ele (R): “(...) cada locutor se apresenta como sujeito, remetendo a ele mesmo como eu do discurso. Por isso, eu propõe outra pessoa, aquela que, sendo embora exterior a 'mim', torna-se o meu eco - ao qual digo tu e me diz tu" (BENVENISTE, 1989, p. 286).

Nessa relação triangular, o espaço (L) e o tempo (T), ou o aqui e o agora, somente podem ser especificados no e pelo processo de produção do discurso, à medida que são função da relação eu/tu $(\mathrm{E} / \mathrm{Ea})$.

Todos esses elementos que integram o triângulo enunciativo constituem a base para a utilização de outras entidades linguísticas: as formas pronominais; os elementos dêiticos, morfemas, palavras e expressões de tempo/lugar, de 
modalidade, etc. É importante ressaltar, no entanto, que tais entidades não se constituem isoladamente, mas integradas e articuladas no e pelo processo enunciativo.

Do ponto de vista da materialidade dos enunciados de um texto, entende-se, aqui, por Instância Enunciativa, ou Instância de Enunciação, uma configuração de enunciados produzida por processos de textualização necessariamente implementados pelos falantes na construção de relações dialógicas entre enunciadores e enunciatários, de modo a situá-los em um determinado tempo e espaço discursivos em que se constitui a referência textual. [Ver GRÁF. 1, anterior]

Ao adotarmos tal pressuposto, retomamos Benveniste (1989, p. 68), que afirma:

Todas as línguas têm em comum certas categorias de expressão que parecem corresponder a um modelo constante. (...) mas suas funçôes não aparecem claramente senão quando se as estuda no exercício da linguagem e na produção do discurso. (Grifos Nossos)

Nesse modelo constante, caracterizado por Benveniste como sendo o Aparelho Formal da Enunciação, representado no GRÁF. 1, anteriormente, a inter-relação entre Enunciador e Enunciatário (E/Ea) é uma condição necessária para que se dê a implementação do processamento discursivo, pois ela constitui o sistema de referências pessoais necessário a que os falantes atualizem a língua por atos de linguagem.

Esse sistema de referências pessoais indicia, no texto oral ou escrito, a implementação de procedimentos e/ou estratégias responsáveis pela construção do Enunciador(E), do Enunciatário(Ea) e da inter-relação entre eles, na construção da Referência (R).

\subsection{Estratégias de construção da relação Eu/Tu}

Segundo Benveniste, os pronomes não constituem uma classe unitária: uns pertencem à sintaxe da língua, outros são característicos das "instâncias do discurso", isto é, “(...) os atos discretos e cada vez únicos pelos quais a língua é atualizada em palavra pelo locutor." (1988, p. 277). É o caso dos pronomes chamados pessoais $e u, t u$, ele, que, embora comumente classificados numa mesma categoria, segundo o autor, não se referem todos à noção de pessoa, pois esta é própria somente de eu/tu e não de ele. 
Nas citaçôes abaixo, podemos verificar como Benveniste define tais formas e como ele as situa no processo enunciativo:

(...) a emergência dos índices de pessoa (a relação eu/tu) não se produz senão na e pela enunciação: o termo 'eu' denotando o indivíduo que profere a enunciação, e o termo 'tu', o indivíduo que aí está presente como alocutário (1989, p. 84).

'Eu' só pode definir-se em termos de 'locução', não em termos de objetos, como signo nominal. 'Eu' significa a pessoa que enuncia a presente instância de discurso que contém 'eu'. (...) 'eu' só pode ser identificado pela instância de discurso que o contém e somente por aí. Não tem valor a não ser na instância na qual é produzido. (...) a forma 'eu' só tem existência lingüística no ato de palavras que a profere. Há, pois, nesse processo uma dupla instância conjugada: instância de 'eu' como referente, e instância de discurso contendo eu, como referido. (...) 'eu' é o indivíduo que enuncia a presente instância de discurso que contém a instância lingüística 'eu'.(...) Essas definiçōes visam eu e tu como uma categoria da linguagem e se relacionam com a sua posição na linguagem (1988, p. 278).

(...) A linguagem previne esse perigo instituindo um signo único, mas móvel, eu, que pode ser assumido por todo locutor, com a condição de que ele, cada vez, só remeta à instância do seu próprio discurso. Esse signo está, pois, ligado ao exercício da linguagem e declara o locutor como tal (1988, p. 281).

(...) os indicadores eu e tu não podem existir como signos virtuais, não existem a não ser na medida em que são atualizados na instância de discurso, em que marcam para cada uma das suas próprias instâncias o processo de apropriação pelo locutor (1988, p. 281).

O eu não denomina, pois, nenhuma entidade lexical.(...) o eu se refere a algo de muito singular, que é exclusivamente lingüístico: eu se refere ao ato de discurso individual no qual é pronunciado, e lhe designa o locutor. É um termo que não pode ser identificado a não ser dentro do que, noutro passo, chamamos uma instância de discurso, e que só tem referência atual. A realidade a qual ele remete é a realidade do discurso (1988, p. 288).

(...) este ato de discurso que enuncia eu aparecerá, cada vez que ele é reproduzido, como o mesmo ato para aquele que o entende, mas para aquele que o enuncia, é cada vez um ato novo, ainda que repetido mil vezes, porque ele realiza a cada vez a inserção do locutor num momento novo do tempo e numa textura diferente de circunstâncias e de discursos (1989, p. 32). 
Note-se que é na relação $e u / t u(E / E a)$ que se dá a possibilidade de produção do discurso, pois ela constitui o sistema de referências pessoais necessário para que os falantes se apropriem da língua e a atualizem pelo ato de linguagem. E esse sistema de referências manifesta-se através da implementação de certas estratégias responsáveis pela construção do Enunciador(E) e do Enunciatário(Ea) no discurso produzido na e pela enunciação.

Numa análise do conjunto das canções de Chico Buarque, podemos observar a presença de estratégias que evidenciam os diferentes tipos de enunciadores e enunciatários construídos pelo autor. Nesse sentido, tomemos duas de suas composiçôes, para exemplificar como tais estratégias manifestam a relação enunciador(E)/enunciatário(Ea):

Ex. 1:

\section{Eu te amo}

Ah, se já perdemos a noção da hora

Se juntos já jogamos tudo fora

Me conta agora como hei de partir

Se, ao te conhecer, dei pra sonhar, fiz tantos desvarios

Rompi com o mundo, queimei meus navios

Me diz pra onde é que inda posso ir

Se nós, nas travessuras das noites eternas

Já confundimos tanto as nossas pernas

Diz com que pernas eu devo seguir

Se entornaste a nossa sorte pelo chão

Se na bagunça do teu coração

Meu sangue errou de veia e se perdeu

Como, se na desordem do armário embutido

Meu paletó enlaça o teu vestido

E o meu sapato ainda pisa no teu

Como, se nos amamos feito dois pagãos

Teus seios inda estão nas minhas mãos

Me explica com que cara eu vou sair

Não, acho que estás te fazendo de tonta

Te dei meus olhos pra tomares conta

Agora conta como hei de partir 
Ex. 2:

\section{Folhetim}

Se acaso me quiseres Sou dessas mulheres Que só dizem sim Por uma coisa à toa Uma noitada boa Um cinema, um botequim

E se tiveres renda Aceito uma prenda Qualquer coisa assim Como uma pedra falsa Um sonho de valsa Ou um corte de cetim
E te farei as vontades Direi meias verdades Sempre à meia luz E te farei, vaidoso, supor Que és o maior e que me possuis

Mas na manhã seguinte Não conta até vinte Te afasta de mim Pois já não vales nada És página virada Descartada do meu folhetim

Os dois exemplos anteriores evidenciam instâncias de enunciação em que as relações entre enunciador e enunciatário diferem, antes de tudo, pelo tipo de enunciador construído: na primeira, o enunciador configura-se na voz de um homem; na segunda, na de uma mulher.

No primeiro exemplo, o título já configura um Eu que se dirige a um Tu declarando seu amor: Eu te amo. No entanto, nem o título, nem os três primeiros versos fornecem uma pista para decidirmos se quem fala é um homem ou uma mulher. Tal pista só aparece no segundo verso da quinta estrofe: Meu paletó enlaça o teu vestido.

A função do léxico na construção de enunciadores e de enunciatários evidencia-se ainda, nessa canção, no primeiro e segundo versos da penúltima estrofe e no primeiro verso da última, respectivamente: Como, se nos amamos feito dois pagãos/ Teu seios inda estão nas minhas mãos" e "Não, acho que estás te fazendo de tonta". Em suma, em 21 versos, somente em 4 temos pistas para a identificação do tipo de enunciador.

Uma vez identificados o enunciador e o enunciatário, podemos reler a canção e operar outros índices de construção da relação entre os dois. Podemos refazer o caminho da construção discursiva da "Individualidade/Subjetividade" de cada um, sempre a partir da "voz" do enunciador.

Podemos, por exemplo, identificar pistas que indiciam o conflito do enunciador entre a consciência da perda da individualidade/identidade decorrente da relação amorosa e a angústia da separação. E esse conflito somente se evidencia pelas marcas de pessoa presentes na canção, que caracterizam os dois tipos de referência $(\mathrm{R})$ correspondentes aos dois aspectos do conflito. 
No primeiro aspecto - a perda da identidade/individualidade do enunciador - a referência é construída pela oposição de dois espaços discursivos, indiciados pelo jogo dos pronomes pessoais e desinências verbais na oposição passado/presente.

No espaço do passado, referenciam-se dados da relação amorosa que se desfaz na perda progressiva da individualidade/identidade do enunciador: $S e$ juntos já jogamos tudo fora/Rompi com o mundo, queimei meus navios/Já confundimos tanto as nossas pernas/Meu sangue errou de veia e se perdeu/Te dei meus olhos pra tomares conta.

A este espaço discursivo referenciado no passado contrapóe-se um espaço discursivo construído no presente da enunciação em que, evidenciando a angústia da separação, o enunciador interpela pungentemente o enunciatário, pedindo, através do uso iterativo de verbos dicendi, ${ }^{3}$ explicações que não lhe são dadas: Me conta como hei de partir/Me diz pra onde é que inda posso ir/Diz com que pernas eu devo seguir/Me explica com que cara eu vou sair/Agora conta como hei de partir.

Já no segundo exemplo, o enunciador (E) instituído é uma mulher, o que se explicita já no segundo verso: Sou dessas mulheres que só dizem sim. E, assim como no primeiro exemplo, é também pelas pistas evidenciadas no restante do texto que se pode identificar as características dessa mulher e quem é o enunciatário (Ea) instituído por ela.

Toda a referência $(\mathrm{R})$ é construída por marcadores que evidenciam a posição da enunciadora(E) diante do enunciatário(Ea): a de quem propõe e estabelece as condições do encontro. Na primeira e segunda estrofes, a enunciadora se apresenta e estabelece as primeiras condiçóes e isso se evidencia pelo uso da partícula condicional se, Se acaso me quiseres/E se tiveres renda, e dos verbos no presente, Sou dessas mulheres/Aceito uma prenda.

$\mathrm{Na}$ terceira estrofe, a enunciadora apresenta o que ela irá oferecer caso as condiçôes estabelecidas no primeiro momento sejam cumpridas, o que se evidencia pelo uso de verbos no futuro $-E$ te farei as vontades/Direi meias verdades/E te farei, vaidoso, supor que és o maior e que me possuis.

Finalmente, na última estrofe, a enunciadora apresenta a última condição para que o encontro se efetive, explicitando o caráter, deliberadamente, fugaz e descompromissado do tipo de relação a que se propõe. O uso do mas-Mas na manhã seguinte - e dos verbos no imperativo - Não conta até vintelTe afasta

${ }^{3}$ Trata-se de verbos que, diretamente, referenciam uma elocução. $\mathrm{Na}$ canção em foco, encontram-se nesta categoria os verbos: contar, dizer e explicar. 
de mim - reiteram a posição assumida pela enunciadora e acentuam o tipo de relação que ela estabelece com o enunciatário.

A relação $\mathrm{eu} / \mathrm{tu}$ pode ser explicitada, ainda, por outros índices formais, que evidenciam a relação dialógica característica do processo enunciativo, tais como: o vocativo, o imperativo, a interrogação, etc. A título de ilustração, tomemos alguns trechos de outras composições de Chico Buarque:

\section{Carolina}

Nos teus olhos fundos

Guarda tanta dor

A dor de todo esse mundo

Eu já lhe expliquei que não vai dar

Seu pranto não vai nada mudar (...)

Meu caro amigo me perdoe, por favor

Se eu não lhe faço uma visita

Mas como agora apareceu um portador

Mando notícias nessa fita

Aqui na terra tão jogando futebol

Tem muito samba, muito choro e rock'n'roll

Uns dias chove, noutros dias bate sol

Mas o que eu quero é lhe dizer que a coisa aqui tá preta (...)

Não é por estar na sua presença

Meu prezado rapaz

Mas você vai mal

Mas vai mal demais

São dez horas, o samba tá quente

Deixe a morena contente

Deixe a menina sambar em paz (...)

Quem é você?

Adivinhe, se gosta de mim

Hoje os dois mascarados

Procuram os seus namorados

Perguntando assim:

Quem é você, diga logo

Que eu quero saber o seu jogo

Que eu quero morrer no seu bloco

Que eu quero me arder no seu fogo (...) 
Estou vendendo um realejo

Quem vai levar

Quem vai levar

Já vendi tanta alegria

Vendi sonhos a varejo

Ninguém mais quer hoje em dia

Acreditar no realejo

Sua sorte, seu desejo

Ninguém mais veio tirar

Então eu vendo o realejo

Quem vai levar (...)

Mirem-se no exemplo daquelas mulheres de Atenas

Vivem pros seus maridos, orgulho e raça de Atenas

Quando amadas se perfumam

Se banham com leite, se arrumam

Suas melenas

Quando fustigadas não choram

Se ajoelham, pedem, imploram

Mais duras penas

Cadenas (...)

(...) Amanhã, ninguém sabe

Traga-me um violão

Antes que o amor acabe

Traga-me um violão

Traga-me um violão

Antes que o amor acabe (...)

Os exemplos anteriores apresentam várias pistas que indicam o momento em que o enunciatário é instituído no discurso pelo enunciador. $\mathrm{O}$ vocativo - Carolinal Meu caro amigo/ Meu prezado rapaz - a interrogação e as formas derivadas desse aspecto - Quem é você? Que eu quero saber/ Adivinhe/Quem vai levar-e o imperativo-Mirem-sel Traga-me-constituem marcas que revelam a relação imediata do enunciador com o enunciatário no momento da enunciação.

\subsection{O processamento dêitico e a construção de instâncias de enunciação}

A construção de Instâncias de Enunciação envolve de maneira crucial os princípios e/ou mecanismos do processamento dêitico. Pode-se dizer que construir uma Instância de Enunciação é instituir um Enunciador e um 
Enunciatário, referenciando sua relação dialógica, interlocutiva, num aqui e agora da Enunciação. São o aqui e o agora que delimitam o tempo e o espaço da instância de discurso a qual pertence o enunciador:

(...) a dêixis é contemporânea da instância de discurso que contém o indicador de pessoa; dessa referência o demonstrativo tira o seu caráter cada vez único e particular, que é a unidade da instância de discurso à qual se refere. O essencial é, portanto, a relação entre o indicador (de pessoa, de tempo, de lugar, de objeto mostrado, etc.) e a presente instância de discurso (1988, p. 279).

Alguns outros indicadores partilham a mesma situação, notadamente a série dos dêiticos. Indicando os objetos, os demonstrativos organizam o espaço a partir de um ponto central, que é Ego, segundo categorias variáveis: o objeto está perto ou longe de mim ou de ti, ele é também orientado (defronte ou detrás de mim, no alto ou em baixo), visível ou invisível, conhecido ou desconhecido, etc. (1989, p. 69-70).

As citações acima evidenciam a importância do processamento dêitico na construção das Instâncias de Enunciação, no processamento discursivo. Considerese, por exemplo, na composição O meu guri, de Chico Buarque, o papel do processamento dêitico na construção da relação enunciador/enunciatário:

Quando, seu moço, nasceu meu rebento

Não era o momento dele rebentar

Já foi nascendo com cara de fome

E eu não tinha nem nome pra lhe dar

Como fui levando, não sei lhe explicar

Fui assim levando, ele a me levar

E, na sua meninice, ele um dia me disse

Que chegava lá

Olha aí

Olha aí

Olha aí, ai o meu guri, olha aí

Olha aí, é o meu guri

E ele chega

Chega suado e veloz do batente

E traz sempre um presente pra me encabular

Tanta corrente de ouro, seu moço

Que haja pescoço pra enfiar

Me trouxe uma bolsa já com tudo dentro

Chave, caderneta, terço e patuá 
Um lenço e uma penca de documentos

Pra finalmente eu me identificar, olha aí

Olha aí, ai o meu guri, olha aí

Olha aí, é o meu guri

E ele chega

Chega no morro com o carregamento

Pulseira, cimento, relógio, pneu, gravador

Rezo até ele chegar cá no alto

Essa onda de assaltos tá um horror

Eu consolo ele, ele me consola

Boto ele no colo pra ele me ninar

De repente acordo, olho pro lado

E o danado já foi trabalhar, olha aí

Olha aí, ai o meu guri, olha aí

Olha aí, é o meu guri

E ele chega

Chega estampado, manchete, retrato

Com venda nos olhos, legenda e as iniciais

Eu não entendo essa gente, seu moço

Fazendo alvoroço demais

O guri no mato, acho que tá rindo

Acho que está lindo de papo pro ar

Desde o começo, eu não disse, seu moço

Ele disse que chegava lá

Olha aí, olha aí

Olha aí, ai o meu guri, olha aí

Olha aí, é o meu guri

A canção institui um Espaço Semântico de Interlocução em que se situa, no aqui/agora da enunciação, uma enunciadora - uma mãe - e um enunciatário referenciado pelo vocativo "seu moço". Toda a referência é construída no espaço semântico dessa interlocução, para cuja composição agencia-se o processamento dêitico, principalmente através de operações que situam enunciadores e enunciatários e suas interlocuções em tempos e espaços discursivos.

Já no primeiro verso da canção, o enunciado - Quando, seu moço, nasceu meu rebento - através de uma operação dêitica, instaura, num mesmo espaço discursivo, o da interlocução Mãe/Seu moço, um tempo referenciado, passado, que se opõe ao Tempo da enunciação. O advérbio Quando promove a ligação com um plano anterior ao momento da fala, também referenciado pelo verbo no passado - nasceu - e, ao mesmo tempo, institui a referência, o assunto sobre o qual se fala. 
A leitura dos demais versos da canção evidencia que, pelo processamento dêitico, toda a referência é construída pela oposição desses dois momentos discursivos, indiciados pelos pronomes pessoais, pelos marcadores temporais e espaciais e pelas desinências verbais de passado e de presente.

Nesse sentido, os elementos que introduzem e finalizam, insistentemente, todas as estrofes da canção, respectivamente - o verbo Chega e o refrão Olha aí, éo men guril E ele chega - configuram-se como operadores discursivos, cuja função é marcar uma oposição reiterada entre passado e presente no eixo da temporalidade construída no processo narrativo. Assim, os versos que antecedem o refrão, sempre construídos no passado, são ressignificados no refrão, que marca o momento presente da enunciação.

Desse modo, o advérbio aí referencia o lugar do enunciatário, criando as condições para o desenvolvimento da argumentação, fornecendo as coordenadas para que o enunciatário situe o enunciado, e funciona também como um operador discursivo de conclusão que referencia o assunto sobre o qual se fala.

A função conclusiva do advérbio aí evidencia-se, principalmente, na última estrofe da canção, em que a enunciadora retoma a referência construída na oposição entre momentos da narrativa colocados em contraposição ao longo do texto, pelo uso de dois marcadores - a expressão adverbial desde o começo e a locução eu não disse, seu moço:

Desde o começo, eu não disse, seu moço

Ele disse que chegava lá

Olha aí, olha aí

Olha aí, ai o meu guri, olha aí

Olha aí, é o meu guri.

Esses marcadores referenciam também os dois espaços que configuram o espaço semântico da interlocução construída na canção - o espaço da enunciação e o espaço da referência, como se a enunciadora afirmasse, ao mesmo tempo: desde o começo da nossa conversa eu lhe disse que ele chegava lá e desde o começo da sua vida, meu filho me disse que ele chegava lá.

Da mesma maneira que o advérbio aí referencia o lugar do enunciatário, outros marcadores indiciam o lugar do enunciador. Na segunda e terceira estrofes, por exemplo, há três versos, respectivamente, que apresentam indicadores dêiticos que evidenciam o espaço e o tempo discursivos do enunciador:

Pra finalmente eu me identificar

Rezo até ele chegar cá no alto

De repente acordo, olho pro lado 
A expressão cá no alto indica o lugar do enunciador no espaço em que a interlocução se efetiva e as expressões finalmente, de repente e pro lado marcam o tempo e o espaço discursivos do enunciador na referência.

Há ainda outros itens que cumprem essa dupla função dêitica, concomitantemente ou não, dependendo do contexto, como, por exemplo, o pronome lhe, no quarto e quinto versos da primeira estrofe. No verso $-E$ eu não tinha nome pra lhe dar - o pronome lhe interpreta-se no âmbito do conteúdo referenciado, o assunto sobre o qual se fala; já no verso Como fui levando não sei lhe explicar, o pronome lhe coloca em referência o enunciatário.

As operações dêiticas envolvidas na configuração do conteúdo referenciado explicitam-se também no uso do advérbio lá, no refrão - Ele disse que chegava lá. O advérbio instancia não o lugar dos enunciadores no discurso, mas o lugar referenciado no eixo da narrativa. $\mathrm{O}$ lá, assim como o ele e outras marcas de terceira pessoa, configura-se como um termo não marcado da correlação de pessoa, como uma não-pessoa, uma referência zero fora da relação eu/tu.

Como afirma Benveniste, a terceira pessoa traz como traço distintivo

(...) a propriedade $1^{\circ}$ de se combinar com qualquer referência de objeto; $2^{\circ}$ de não ser jamais reflexiva da instância de discurso; $3^{\circ}$ de comportar um número às vezes bastante grande de variantes pronominais ou demonstrativas; $4^{\circ}$ de não ser compatível com o paradigma dos termos referenciais como aqui, agora, etc. (1988, p. 283).

Desse modo, os indicadores de terceira pessoa funcionam como elementos dêiticos, à medida que exercem o papel de instituir um dos fatores que integram e condicionam a instância de enunciação: a referência.

As instâncias enunciativas configuram-se, assim, através de operações que articulam o tempo da enunciação e os tempos/espaços referenciados na e pela atividade discursiva. Tempo e espaço discursivos são construídos, portanto, no e pelo processamento dêitico, através da interligação dos fatores básicos constituintes do processo enunciativo: enunciador, enunciatário e referência.

É importante ressaltar que os elementos linguísticos do aparelho formal são o que Benveniste denomina de condições iniciais que irão reger todo o mecanismo da referência no processo de enunciação.

$\mathrm{O}$ ato individual de apropriação da língua introduz aquele que fala em sua fala. Este é um dado constitutivo da enunciação. A presença do locutor em sua enunciação faz com que cada instância de discurso constitua um centro de referência interno. Esta situação vai se 
manifestar por um jogo de formas específicas cuja função é de colocar o locutor em relação constante e necessária com sua enunciação (1989, p. 84).

No plano da materialidade do texto, os elementos dêiticos funcionam, portanto, como pistas linguísticas que nos possibilitam identificar e situar os processos e mecanismos linguísticos que constituem o aparelho formal responsável pelo acontecimento discursivo.

\section{A articulação de instâncias enunciativas no processamento discursivo: Trocando em Miúdos}

Neste item, tentaremos identificar e analisar, de forma processual, como se integram e se articulam as estratégias exemplificadas nos itens anteriores, com o objetivo de construir a relação enunciador/enunciatário. Para isso, tomaremos como objeto de análise a composição Trocando em Miúdos:

Eu vou lhe deixar a medida do Bonfim

Não me valeu

Mas fico com o disco do Pixinguinha, sim?

O resto é seu

Trocando em miúdos, pode guardar

As sobras de tudo que chamam lar

As sombras de tudo que fomos nós

As marcas de amor nos nossos lençóis

As nossas melhores lembranças

Aquela esperança de tudo se ajeitar

Pode esquecer

Aquela aliança, você pode empenhar

Ou derreter

Mas devo dizer que não vou lhe dar

$\mathrm{O}$ enorme prazer de me ver chorar

Nem vou the cobrar pelo seu estrago

Meu peito tão dilacerado

Aliás

Aceite uma ajuda do seu futuro amor

Pro aluguel

Devolva o Neruda que você me tomou

E nunca leu

Eu bato o portão sem fazer alarde 
Eu levo a carteira de identidade

Uma saideira, muita saudade

E a leve impressão de que já vou tarde

$\mathrm{Na}$ composição em foco, podemos perceber claramente que o autor se constitui como um enunciador (E) bastante específico - o maridolamante, que se dirige à enunciadora $(\mathrm{A})$ - esposalamante, para falar do relacionamento dos dois (R) no momento (T/L) da separação. Nesse espaço de interlocução, os fatores, evidentemente, da relação enunciador/enunciatário, podem ser explicitados pela identificação de determinadas estratégias, tais como: a escolha lexical, o uso dos pronomes e verbos, a dêixis, etc. Vejamos, assim, como se caracterizam tais estratégias na macro-estrutura do texto.

Percebe-se que a canção é marcada por três espaços discursivos, em que se referenciam, respectivamente, três sentimentos do enunciador sobre o relacionamento amoroso: um sentimento de mágoa e nostalgia, um sentimento de impossibilidade e um sentimento de perda e solidão.

O primeiro, iniciado pelo uso do pronome $E \mathcal{E}$, marca claramente a posição do enunciador, o seu ponto de vista sobre o relacionamento. Notase uma tentativa de interação, de aproximação com o enunciatário, evidenciada pelas duas primeiras estrofes: Eu vou the deixar a medida do Bonfim/ não me valeu; Mas fico com o disco do Pixinguinha, sim?/ o resto éseu.

A afirmação/constatação seguida de um pedido de concordância demonstra a tentativa do enunciador de estabelecer uma interlocução. A interrogação indica a sua espera de um posicionamento/resposta do enunciatário e o uso do operador Mas ameniza o tom ressentido da primeira afirmação e sugere a possibilidade de um diálogo.

No entanto, essa possibilidade é logo quebrada na passagem para o outro verso: Trocando em miúdos, pode guardar, que evidencia o ressentimento com que o enunciador se refere ao relacionamento. E esse ressentimento é reforçado pelo tom nostálgico e melancólico dos versos seguintes, em que os verbos aparecem no passado e as expressóes pressupõem a existência de uma forte intimidade entre os dois, num tempo anterior ao momento da enunciação, intimidade esta que, do ponto de vista do enunciador, só pode ficar na lembrança.

A tentativa de interação com o enunciatário é, portanto, decorrente da representação que o enunciador faz do relacionamento amoroso. O uso do pronome nós indica a idéia de que ele acredita que o enunciatário também compartilha do mesmo ponto de vista: As sombras de tudo que fomos nós/ As marcas de amor nos nossos lençóis/ As nossas melhores lembranças. 
Vale lembrar, aqui, como Benveniste define/caracteriza esse tipo de pronome:

(...) o plural pronominal não coincide com o plural nominal, pelo menos tal como se representa ordinariamente. Está claro, de fato, que a unicidade e a subjetividade inerentes a 'eu' contradizem a possibilidade de uma pluralização. Se não pode haver vários 'eu' concebidos pelo próprio 'eu' que fala, é porque 'nós' não é uma multiplicação de objetos idênticos mas uma junção entre o 'eu' e o 'não-eu', seja qual for o conteúdo desse 'não-eu'. Essa junção forma uma totalidade nova e de um tipo totalmente particular, no qual os componentes não se equivalem: em 'nós' é sempre 'eu' que predomina, uma vez que só há 'nós' a partir de 'eu' e esse 'eu' sujeita o elemento 'não-eu' pela sua qualidade transcendente. A presença do 'eu' é constitutiva do 'nós' (1988, p. 256).

O uso do nós evidencia, assim, a dualidade de sentimentos do enunciador diante da separação. Por um lado, as melhores lembranças, as marcas de amor nos nossos lençóis, levam-no à busca de uma interação com o enunciatário, no sentido de compartilhar o seu ponto de vista, a sua representação sobre a dissolução do relacionamento. Por outro lado, a constatação de que essas lembranças e marcas são apenas sombras do que poderia ter sido, impossibilita essa interação.

Essa dualidade do enunciador se manifesta mais claramente no trecho As sobras de tudo que chamam lar. Nesse trecho, o verbo dicendi - chamarevidencia a presença de um outro enunciador que, ainda que indeterminado, introduz um ponto de vista contrário ao do enunciador/marido. E é essa dualidade de sentimentos que possibilita a passagem para um segundo momento da enunciação, em que o enunciador, ao expor sua mágoa e decepção ao enunciatário, constata a impossibilidade de uma reconciliação.

Desse modo é que trechos como: Aquela esperança de tudo se ajeitar/ pode esquecer; Aquela aliança, você pode empenharl ou derreter - somente podem ser interpretados/significados no âmbito da instância de enunciação, na e pela constituição do jogo de imagens e representações criadas entre os interlocutores, no processo de constituição da sua intersubjetividade.

O pronome demonstrativo Aquela funciona como um elemento dêitico que articula e organiza a referência $(\mathrm{R})$ e constrói/condiciona os demais fatores que integram o triângulo enunciativo - enunciador/enunciatário, tempo/espaço. A presença desse pronome introduz, assim, dois tipos de referência: no primeiro caso - Aquela esperança de tudo se ajeitar/pode esquecer - ativa uma outra instância de enunciação, à medida que o enunciado pressupõe uma conversa anterior entre enunciador/enunciatário; no segundo caso - 
Aquela aliança, você pode empenharl ou derreter - indica, aponta um objeto comum, símbolo da relação amorosa, entre os interlocutores e fornece as coordenadas para que o enunciatário situe o enunciado, funcionando como um modo particular de atualização de uma informação.

Todas essas informações presentes no texto somente podem ser ativadas e articuladas na e pela instanciação que se estabelece entre os interlocutores, e somente dentro dela podem compor o sentido do discurso. Assim, expressões, como medida do Bonfim; disco do Pixinguinha; marcas de amor nos nossos lençóis; nossas melhores lembranças; o resto é seu; etc., revelam-se como elementos representativos da intimidade que se estabelece entre enunciador/enunciatário, à medida que constituem a espacialidade $(\mathrm{L})$ e a temporalidade( $\mathrm{T})$ da instância enunciativa. Essas expressões organizam as informações e situam os interlocutores no processo discursivo.

Ainda na segunda estrofe - correspondente ao segundo espaço discursivo do processo enunciativo - o verbo dizer, no trecho Mas devo dizer que não vou the dar o enorme prazer de me ver chorar, bem como o seu correlato - cobrarNem vou lhe cobrar pelo seu estrago, definem a posição do enunciador diante da separação. O enunciador expõe seu sentimento de mágoa e infelicidade, mas corta qualquer possibilidade de interação com o enunciatário. Isso se evidencia pelo uso do operador Mas, que delimita os dois pontos de vista: o da mágoa e o do afastamento.

Finalmente, o terceiro espaço discursivo é explicitado pelo uso do Aliás, que tem uma função análoga ao uso da expressão trocando em miúdos da primeira estrofe, mas define, de maneira ainda mais radical, o ponto de vista construído na enunciação. O uso do Aliás introduz a idéia de ruptura, de quebra de um possível tom amistoso que até então pudesse ter sido construído pelo enunciatário, funcionando como um elemento de desativação do efeito de sentido construído inicialmente, e de estabelecimento de um ponto de vista importante na construção da referência, no espaço discursivo da enunciação.

Esse posicionamento do enunciador é reiterado pela sua saída e pelo tom irônico com que tenta encobrir o seu ressentimento - Aceite uma ajuda do seu futuro amor pro aluguel/ Devolva o Neruda que você me tomou e nunca leu - a sua decepção e o seu sentimento de perda e solidão - Eu bato o portão sem fazer alardel Eu levo a carteira de identidadel Uma saideira, muita saudadel E a leve impressão de que já vou tarde.

E é na pauta desse ponto de vista que todo o texto pode ser re-significado e reinterpretado, pois os tempos passado/presente/futuro, evidenciados nos três espaços discursivos, respectivamente, são sempre co-ordenados pelo eixo do 
enunciador eu-aqui-agora. Os tempos verbais, portanto, não aparecem aleatoriamente, sua utilização deve ser considerada um fator de criação e articulação das instâncias enunciativas no discurso.

Nessa perspectiva, a escolha lexical também constitui uma importante estratégia discursiva, que atua na constituição do sentido do texto. A escolha dos nomes e verbos se organiza de tal forma que podemos agrupá-los em campos semânticos correspondentes aos três espaços discursivos. O primeiro sugere a temática da rememoração, da lembrança do que foi a relação e do que ela poderia ter sido e não foi, aos olhos do enunciador. Daí o uso de termos como sobras, sombras, lembranças, marcas - e de verbos como - guardar, valeu, fomos. O segundo sugere a temática do ressentimento, da mágoa e da impossibilidade, daí o uso de verbos como esquecer, derreter, empenhar, chorar e de termos como estrago e dilacerado. O terceiro e último espaço insere-se na temática da solidão e do vazio e é marcado pelo uso de termos como saideira, saudade, impressão, tarde e de verbos como devolva, bato, levo, vou.

É interessante observar que esse agrupamento semântico pode ser evidenciado também pelo uso dos pronomes pessoais, que marcam três formas de manifestação da relação enunciador/enunciatário, correspondentes aos sentimentos expressos em cada um dos espaços. No primeiro, predomina o uso do nós, evidenciando a tentativa de interação já explicitada no início deste item. No segundo, há uma nítida separação do nós, que se transforma em eu e $t u$, evidenciando a impossibilidade da relação. Finalmente, no terceiro, o predomínio do eu, que explicita o sentimento de solidão e de vazio do enunciador.

Cabe ressaltar ainda dois aspectos evidenciados, respectivamente, no primeiro e no terceiro espaços discursivos do processo enunciativo: as referências a Pixinguinha e a Pablo Neruda, à medida que elas também podem ser reinterpretadas quando tomadas em função do ponto de vista evidenciado nos três espaços discursivos.

É interessante notar que a referência a Pixinguinha parece construir nessa canção um efeito de sentido semelhante ao que produz a mesma referência na composição Para Todos, do mesmo autor:

\author{
(...) Para um coração mesquinho \\ Contra a solidão agreste \\ Luiz Gonzaga é tiro certo \\ Pixinguinha é inconteste \\ Tome Noel, Cartola, Orestes \\ Caetano e João Gilberto (...)
}


Nesse contexto, o enunciado Mas fico com o disco do Pixinguinha, sim? se configura como um recurso, uma estratégia utilizada pelo autor da composição no sentido de ressaltar o sentimento de solidão vivenciado pelo enunciador. Do mesmo modo, a referência ao poeta Neruda é também bastante significativa, à medida que esse autor é conhecido como o poeta do amor. Assim, o enunciado Devolva o Neruda que você me tomou e nunca leu parece funcionar como um desabafo do enunciador, como se ele estivesse dizendo: Devolva o amor que você me tomou e nunca entendeu.

Tudo isso nos permite perceber como os elementos envolvidos na construção do tempo e espaço enunciativos, quando analisados fora de seu contexto de produção, não representam os momentos enunciativos que constituem o processo discursivo. A enunciação constitui, assim, o seu espaço/tempo, que é o aqui-agora da relação que se estabelece no e pelo discurso entre enunciador e enunciatário.

Sendo assim, o título da canção, que remete a elementos do cotidiano, só pode ser interpretado no interior dessa instância de enunciação, ou seja: um desabafo do amante/marido que, no momento da separação, explicita a intimidade do casal, intimidade esta que somente pode ser entendida e significada pelos dois, nesse momento.

Dessa forma, a ativação dos dois termos - trocando e miúdos - opera propriedades semânticas que permitem a construção da referência do discurso pelo processamento de determinadas informações já compartilhadas pelo enunciatário. $\mathrm{O}$ título funciona, assim, como uma forma de enquadramento da relaçãao enunciador/enunciatário que se pretende estabelecer na enunciação como um todo, à medida que reflete a ideia de conclusão, de acerto de contas.

\section{Instâncias de enunciação como espaços de construção da subjetividade}

Ao especificar e definir os elementos e categorias que constituem o quadro formal responsável pela efetivação da enunciação, Benveniste atribui à linguagem a condição primeira de instauração da subjetividade, pois é na pela interação que o enunciador estabelece com seu enunciatário que ele pode se propor como sujeito:

A linguagem é, pois, a possibilidade da subjetividade, pelo fato de conter sempre as formas lingüísticas apropriadas à sua expressão; e o discurso provoca a emergência da subjetividade, pelo fato de consistir 
de instâncias discretas. A instância de discurso é assim constitutiva de todas as coordenadas que definem o sujeito e das quais apenas designamos sumariamente as mais aparentes (1988, p. 289).

Embora haja críticas ${ }^{4}$ à noção de subjetividade de Benveniste, fundamentadas na ideia de que ele restringe a noção de sujeito ao Ego e coloca o Tu como figura complementar, considero que o sujeito de Benveniste só é possível de ser entendido na interação, na relação eu/tu que se estabelece na e pela linguagem e não no predomínio de um sobre o outro:

É numa realidade dialética que englobe os dois termos e os defina pela relação mútua que se descobre o fundamento lingüístico da subjetividade (1988, p. 287).

A consciência de si mesmo só é possível se experimentada por contraste. Eu não emprego eu a não ser dirigindo-me a alguém, que será na minha alocução um tu. Essa condição de diálogo é que é constitutiva da pessoa, pois implica reciprocidade. (...) A linguagem só é possível porque cada locutor se apresenta como sujeito, remetendo a ele mesmo como eu no seu discurso. (...) A polaridade das pessoas é na linguagem a condição fundamental, cujo processo de comunicação, de que partimos, é apenas uma conseqüência totalmente pragmática (...) nenhum dos dois termos (eu/tu) se concebe sem o outro (1988, p. 286).

A intersubjetividade tem assim sua temporalidade, seus termos, suas dimensōes. Por aí se reflete na língua a experiência de uma relação primordial, constante, indefinidamente reversível, entro o falante e seu parceiro. Em última análise, é sempre ao ato de fala no processo de troca que remete a experiência humana inscrita na linguagem (1989, p. 80).

É na instância de discurso na qual eu designa o locutor que este se enuncia como sujeito. É portanto verdade que o fundamento da subjetividade está no exercício da língua. Os pronomes pessoais são o primeiro ponto de apoio para essa revelação da subjetividade na linguagem (1988, p. 288).

(...) cada locutor se apresenta como sujeito, remetendo a ele mesmo como eu do Discurso. Por isso, eu propóe outra pessoa, aquela que, sendo embora exterior a "mim", torna-se o meu eco - ao qual digo tu e me diz tu. A polaridade das pessoas é na linguagem a condição fundamental, cujo processo de comunicação, de que partimos, é apenas uma conseqüência pragmática (1989, p. 286).

${ }^{4}$ Cf. BRANDÃO. Subjetividade, argumentação e polifonia. 
O sujeito é constituído, portanto, quando um $e u$ (enunciador) dirigese a um $t u$ (enunciatário), constituindo-se cada um no seu eu e vendo no outro um $t u$. Essa polaridade é que possibilita a produção do discurso. O sujeito de Benveniste somente se constitui na relação linguística entre $e u$ e $t u$, em que um não existe sem o outro.

Ao colocar o sujeito no centro da atividade linguística e mostrar que esse sujeito não se pode distinguir da instância de discurso que o produziu, Benveniste evidencia que: "o sujeito não é anterior à linguagem; só se torna sujeito na medida em que fala; em suma, não há 'sujeitos' (e, portanto, 'subjetividade'), há apenas locutores; mais ainda - e é uma instância constante de Benveniste - só há interlocutores." (BARTHES, 1984, p. 151).

Nessa perspectiva é que Benveniste critica a noção de linguagem como instrumento, pois para ele é na e pela linguagem que o homem se constitui:

$\mathrm{Na}$ realidade, a comparação da linguagem como um instrumento (...) deve encher-nos de desconfiança, como toda noção simplista a respeito da linguagem. (...) Não atingimos nunca o homem separado da linguagem e não o vemos nunca inventando-a.(...) É um homem falando que encontramos no mundo, um homem falando com outro homem, e a linguagem ensina a própria definição do homem (1988, p. 285).

As estratégias aqui explicitadas e analisadas revelam-se, portanto, como uma evidência do trabalho do autor, ${ }^{5}$ à medida que são resultantes de suas escolhas enquanto responsável pela ativação dos elementos que integram o processo enunciativo. O autor se apresenta, assim, como a instância a partir da qual os enunciadores e enunciatários se constituem, como uma entidade linguisticamente estabelecida e que só tem existência se considerada no interior da própria enunciação.

Adotando-se tal ponto de vista, a subjetividade constitui uma das variáveis que compõem os elementos da enunciação, dado que os enunciados resultam de uma estratégia de seleção lexical, de um trabalho do autor, na e pela linguagem. $\mathrm{O}$ discurso construído pelo autor, ao revelar o ponto de vista do enunciador nele e por ele instituído, configura-se como um metadiscurso, em que a voz da autoria explicita-se pela voz dos enunciadores instituídos na e pela enunciação.

${ }^{5} \mathrm{O}$ termo Autor é entendido aqui como o conjunto de decisões e procedimentos adotados pelo responsável por colocar em cena os enunciadores, ou, no sentido de AutorModelo de Umberto Eco (1979), como instância a partir da qual os enunciadores se constituem, uma entidade linguística que se constrói no e pelo processamento discursivo. 


\section{Referências}

BARTHES, Roland. Por que gosto de Benveniste. In.: O rumor da língua. Trad. António Gonçalves Lisboa, Portugal: Ediçóes 70, 1984. p.149-152. BENVENISTE, Emile. Problemas de lingüistica geral I. Trad. Maria da Glória Novak e Maria Luiza Neri. 2. ed. Campinas: Pontes e Editora da Unicamp, 1988. 387p.

Problemas de lingüistica geral II. Tradução de Eduardo Guimarães et al. Campinas: Pontes e Editora da Unicamp, 1989. 294p.

BRANDÃO, Helena N. Subjetividade, argumentação e polifonia. A propaganda da Petrobrás. São Paulo: Fundação Editora da Unesp, 1998. 191p.

ECO, Umberto. Lector in fabula: a cooperação interpretativa nos textos narrativos.Tradução de Attílio Cancian. São Paulo: Perspectiva, 1979. 219p.

HOLlANDA, Chico Buarque de. Chico Buarque, letra e música. São Paulo: Companhia das Letras, 1989. 295p.

NASCIMENTO, Milton do. Texto, hipertexto e intertextualidade. Belo Horizonte, 2000. 23f. Não Publicado.

VIEIRA, Martha Lourenço. O papel da composição da cena enunciativa no processo de aquisição do texto escrito. 2004. 249 f. Tese (Doutorado em Educação e Linguagem) - Faculdade de Educação, Universidade de São Paulo, São Paulo, 2004.

Recebido em fevereiro de 2008. Aprovado em maio de 2008. 